\title{
Quantifying the Financial Impacts of Net-Metered PV on Utilities and Ratepayers
}

\author{
Andrew Satchwell ${ }^{\mathrm{a},}$, Andrew Mills ${ }^{\mathrm{b}}$, and Galen Barbose ${ }^{\mathrm{c}}$ \\ ${ }^{a}$ Lawrence Berkeley National Laboratory, 1 Cyclotron Road, Mailstop 90R4000, Berkeley, CA 94720 USA, \\ ASatchwell@lbl.gov \\ ${ }^{\mathrm{b}}$ Lawrence Berkeley National Laboratory, 1 Cyclotron Road, Mailstop 90R4000, Berkeley, CA 94720 USA, \\ ADMills@lbl.gov \\ ${ }^{\mathrm{c}}$ Lawrence Berkeley National Laboratory, 1 Cyclotron Road, Mailstop 90R4000, Berkeley, CA 94720 USA, \\ GLBarbose@lbl.gov
}

\begin{abstract}
Deployment of customer-sited photovoltaics (PV) in the United States has expanded rapidly in recent years, driven by falling PV system prices, the advent of customer financing options, and various forms of policy support at the federal, state, and local levels. With the success of these efforts, heated debates have surfaced in a number of U.S. states about the impacts of customer-sited PV on utility shareholders and ratepayers. We performed a scoping analysis using a financial model to quantify the financial impacts of customer-sited PV on utility shareholders and ratepayers and to assess the magnitude of these impacts under alternative utility conditions. We find that customer-sited PV generally reduces utility collected revenues greater than reductions in costs leading to a revenue erosion effect and lost future earnings opportunities. We also find that average retail rates increase as utility costs are spread over a relatively smaller sales base. We analyze these results under various assumptions about utility operating and regulatory environments and find that these impacts can vary greatly depending upon the specific
\end{abstract}

\footnotetext{
* Corresponding author: Tel.: +1 510 4866544; fax: +1 5104866996
} 
circumstances of the utility. Based on this analysis, we highlight potential implications for policymakers and identify key issues warranting further analysis.

\section{Introduction ${ }^{1}$}

Electricity generation from customer-sited photovoltaic (PV) systems currently constitutes just $0.2 \%$ of total U.S. electricity consumption; though it has reached higher penetration levels in various states and utility service territories, and has grown at a rapid pace of roughly $50 \%$ per year over the past decade. $^{2}$ This recent growth has been fueled by a combination of falling PV system prices, the advent of customer financing options, and various forms of policy support at the federal, state, and local levels that are premised on the range of societal benefits that PV may provide. One critical element in the value proposition has been net energy metering (NEM or simply "net metering"), a billing mechanism that allows customers to export electricity generated by their PV systems to the grid and apply that excess generation against electricity consumption at other times, in effect receiving credit for all PV generation at the prevailing retail electric rate. ${ }^{3}$

\footnotetext{
${ }^{1}$ Abbreviations: APS - Arizona Public Service; CAGR - compound annual growth rate; CapEx - capital expenditures; EE - energy efficiency; FAC - fuel adjustment clause; GRC - general rate case; ISO-NE Independent System Operator New England; NAPEE - National Action Plan for Energy Efficiency; NE northeast; NEM - net energy metering; NPV - net present value; O\&M - operations and maintenance; PPA - purchased power agreement; PV - solar photovoltaic; ROE - return-on-equity; RPS - renewable portfolio standard; SW - southwest; T\&D - transmission and distribution; TOU - time-of-use

${ }^{2}$ The highest state-level penetration rates for customer-sited PV are in Hawaii (3.8\% of retail electricity sales at year-end 2013), New Jersey (1.7\%), and California (1.1\%), while the highest penetration rates for individual investor-owned utilities are for the three largest Hawaii utilities (5.1\%-6.0\%), Pacific Gas \& Electric (2.3\%), San Diego Gas \& Electric (2.0\%), and Arizona Public Service (2.0\%). These values are derived from data on customer-sited PV capacity installed through year-end 2013, as reported by GTM/SEIA (2014) and by SEPA (2014).

${ }^{3}$ There are several alternatives to NEM as a compensation mechanism for distributed generation, but we focus on NEM in this paper because it is the predominant approach for distributed PV.
} 
Heated debates surrounding the financial impact of customer-sited PV and net metering on utility shareholders and ratepayers have surfaced in a number of states, and these will likely become more widespread as solar deployment expands, and as states approach statutory caps on the allowed amount of net-metered $\mathrm{PV}^{4}$ Utility executives are often concerned about revenue erosion and reduced shareholder returns when customers with net-metered PV are able to avoid charges for fixed infrastructure costs, as well as potential cost-shifting between solar and nonsolar customers. At the same time, net metering is viewed as essential by customers with PV to protect their investments, by the solar industry to grow their businesses, and by states and environmental advocates to achieve climate or other environmental policy goals. To date, however, progress on these issues has been hampered by a lack of evidence about the magnitude of the financial impacts on utility shareholders and ratepayers and the conditions under which those impacts may become more or less significant.

Quantitative analyses relating to the financial or economic impacts of customer-sited PV and net metering have thus far consisted mostly of cost-benefit studies performed from the perspective of utility ratepayers or society more broadly; see Hansen et al. (2013) for a metaanalysis of cost-benefit studies and E3 (2014) for a more recent example. The results of those studies hinge on the methods and assumptions used to estimate the value of distributed PV to the utility, and considerable disagreement exists around which particular sources of value to consider and how to quantify them (APPA 2014, Bradford and Hoskins 2013, Cliburn and Bourg 2013, Keyes and Rábago 2013, Stanton and Phelan 2013). Competing studies have thus often led to divergent results (E3 2013, Beach and McGuire 2013). By comparison, few analyses beyond

\footnotetext{
${ }^{4}$ Recent challenges to existing net metering tariffs have been raised in regulatory proceedings in Arizona, California, Colorado, Georgia, Idaho, Louisiana, and Nevada (among others); and issues related to the potential rate impacts or cost-shifting from net metering have been prominently featured within energy policy forums (Borenstein 2013) and among major news outlets (Cardwell 2013, Tracy 2013).
} 
several recent research notes by Wall Street analysts (Dumoulin-Smith et al. 2013, Goldman Sachs Global Investment Research 2013) and a limited base of theoretical work (Oliva and MacGill 2012) have sought to examine the financial implications of net metering for utility shareholders. Moreover, little if any published research has quantitatively compared possible options for mitigating any potential adverse impacts on either utility shareholders or ratepayers.

This paper seeks to build upon, and address gaps within, the aforementioned body of research through a scoping analysis that quantifies the potential financial impacts of net-metered PV on utility shareholders and ratepayers ${ }^{5}$. The analysis leverages a pro-forma utility financial model that developed for the purpose of analyzing the shareholder and ratepayer impacts of utility-sponsored EE programs (Cappers et al. 2009, Cappers and Goldman 2009a, Cappers et al. 2010, Satchwell et al. 2011). Our analysis results are based on characterizations of two prototypical utilities: a vertically integrated utility in the southwest ("SW Utility") and a wiresonly utility and default service supplier in the northeast ("NE Utility"). The choice of these two prototypical utilities was intended to capture both a broad spectrum of utility operating and regulatory environments, as well as two regions of the United States that have thus far seen the greatest levels of customer-sited PV deployment.

For each utility and under a range of PV penetration levels, we model the impact of netmetered PV on utility costs, revenues, average rates, and utility shareholder earnings and returnon-equity (ROE). We also examine the sensitivity of those impacts to various aspects of the utility operating and regulatory environment (e.g., load growth, cost growth, the frequency of

\footnotetext{
${ }^{5}$ The work in this article is based on a longer technical report (Satchwell et al 2014a), entitled Financial Impacts of Customer-Sited PV on Utilities and Ratepayers: A Scoping Study of Two Prototypical Utilities (LBNL-XXXX) available at emp.lbl.gov/publications.
} 
general rate cases), as well as to alternate assumptions about the value of PV to the utility (i.e., avoided costs). ${ }^{6}$

\section{Methods}

We used a pro forma financial model that calculates utility costs and revenues, based on specified assumptions about its physical, financial, operating, and regulatory characteristics. Figure 1 depicts the financial model inputs and calculations. The model was adapted from a tool (the Benefits Calculator) initially constructed to support the National Action Plan on Energy Efficiency (NAPEE) and intended to analyze the financial impacts of EE programs on utility shareholders and ratepayers under alternative utility business models (NAPEE 2007). The model was expanded and applied to evaluate the impact of aggressive EE programs on utilities in the U.S. (Cappers and Goldman, 2009a, 2009b; Cappers et al., 2010; Satchwell et al., 2011) and for the present analysis focusing on customer-sited PV.

The model quantifies the utility's annual costs and revenues over a 20-year analysis period. Importantly, the model performs all calculations at the total utility level, and does not differentiate among rate classes or between PV participants and non-participants. As such, we do not directly quantify cost-shifting or cross-subsidization among customer classes, although the modeled impacts on average retail electricity rates may, under many of the scenarios, be considered a proxy for the impacts on non-PV customers. Utility costs are based on model inputs that characterize current and projected utility costs over the analysis period. Some costs

\footnotetext{
${ }^{6}$ Issues surrounding the impacts of customer-sited PV and net metering are complex, and discussions of these issues are invariably contentious. This study is not intended to be a detailed analysis of the value of PV. It relies on a financial model, not a utility production cost or planning model. This financial model contains a relatively high level of detail in its representation of utility ratemaking and revenue collection processes, but less detail in its representation of the physical utility system. As a result, the impacts of distributed PV on utility cost-of-service are based on a coarser set of assumptions than what might be possible with utility operations or planning models. For this reason, we include sensitivity analyses to examine how the financial impacts of PV would vary with alternate assumptions related to avoided costs.
} 
are projected using stipulated compound annual growth rates (CAGRs); other costs are based on schedules of specific investments (e.g., generation expansion plans). The costs cover several categories of the utility's physical, financial, and operating environment, including fuel and purchased power, operations and maintenance, and capital investments in generation and nongeneration assets (i.e., transmission and distribution investments).

The utility's collected revenues are based on retail rates that are set in periodic general rate cases (GRCs) throughout the analysis period (see Figure 1). By default, the model assumes that rate cases occur at some specified frequency, though the model also allows the utility to file a GRC when making large capital investments.

GRCs are used to establish new rates based on the revenue requirement set in a test year (including an authorized ROE for capital investments), the test year billing determinants (i.e., retail sales, peak demand, and number of customers), and assumptions about how the test year revenue requirement is allocated among the billing determinants. The model allows for different types of test years (i.e., historical test years, current test years, and future test years). ${ }^{7}$ The particular rate design of the utility consists of a combination of a volumetric energy charge $(\$ / \mathrm{kWh})$, volumetric demand charge $(\$ / \mathrm{kW})$, and fixed customer charge (\$/customer). Model inputs specify the relative size of those three rate components, and can be modified to represent different rate designs. The model used for this study did not have the capability to represent more complex rate designs, such as time-of-use (TOU) pricing or tiered (i.e., inclining or declining block) rates.

The rates established in a GRC are then applied to the actual billing determinants in future years to calculate utility collected revenue in those years. The model accounts for a period

\footnotetext{
${ }^{7}$ Many states allow the utility to file an adjustment to its historical test-year costs during a GRC (i.e., proforma adjustment period) to update and correct them to better reflect expectations about normal cost levels.
} 
of regulatory lag whereby rates established in a GRC do not go into effect until some specified number of years after the GRC. In between rate cases, certain costs are passed directly to customers through rate-riders (e.g., fuel-adjustment clause [FAC]). Our average all-in retail rate metric, a measure of impacts from the utility customer perspective, reflects the average revenue collected per unit of sales which accounts for periodic setting of new rates, rate-riders, and delays in implementing new rates.

The financial performance of the utility is measured by the achieved after-tax earnings and achieved after-tax ROE, both of which are commonly used by utility managers and shareholders. We calculated the prototypical utilities' achieved after-tax ROE in each year as the current year's earnings divided by current year's outstanding equity (i.e., the equity portion of the ratebase). ${ }^{8}$ Achieved after-tax ROE may - and often does - differ from the utility's authorized ROE, which is established by regulators in a GRC and is used to determine the amount of return a utility can receive on its capital investments. This is because utility rates are set such that the test-year revenue requirement (based on the test year costs and billing determinants) would produce earnings that are sufficient to reach the authorized after-tax ROE. Actual utility revenues and costs may differ from those in the test year, leading to achieved earnings, and hence achieved ROE, that deviates from the authorized level. In general, achieved ROE will be less than authorized ROE if, between rate cases, utility costs grow faster than revenues. Conversely, achieved ROE will generally be greater than authorized ROE if, between rate cases, utility costs grow slower than revenues.

We calculated the prototypical utilities' achieved after-tax earnings as collected revenues minus costs in each year. Similar to achieved after-tax ROE, achieved after-tax earnings can be

\footnotetext{
${ }^{8}$ The model does not take into account cash flow and changes in financing costs that may result from under- or over-recovery of costs, which may impact ROE.
} 
different than the utility's authorized earnings, because the achieved earnings are based on actual profitability in a given year and the authorized earnings are set in the GRC revenue requirement, based on the authorized ROE.

\section{Results}

\subsection{Base Case Results}

We characterize the financial impacts of customer-sited PV on the two prototypical utilities, under our base case utility characterizations and at varying PV penetration levels. We begin by describing impacts of PV on the utilities' retail sales and peak demand, utility costs (i.e., revenue requirements), and utility collected revenues. We then describe utility shareholder impacts in terms of changes to achieved after-tax average ROE and achieved after-tax earnings, and describe ratepayer impacts in terms of changes to customer all-in average retail rates. This approach to modeling the financial impacts of PV, and the metrics used to measure those impacts, are largely analogous to those used in previous studies of the shareholder and ratepayer impacts of customer EE programs (Cappers et al., 2009a, Cappers et al., 2009b, Cappers et al., 2010 and Satchwell et al., 2011).

Importantly, the base case results should not be interpreted as representative of an "expected-case" scenario or as indicative of what any particular utility might experience. Rather, the purpose of the base case analysis is, first to provide a vehicle for explaining how changes in our modeled metrics (average retail rates and utility shareholder ROE and earnings) derive from the underlying impacts of customer-sited PV on utility revenues and costs, and how those impacts are related to the timing of GRCs. Second, the base case results serve as the reference point for the sensitivity analysis presented later in this section. 
Customer-sited PV adoption is a model input assumption. We specify annual capacity additions of customer-sited PV, such that the proportion of retail sales met by customer-sited PV grows linearly over the first 10 years of the analysis period (2013-2022). We examine four different PV penetration trajectories, which grow from 0\% in 2012 to reach terminal penetration levels in 2022 equal to $2.5 \%, 5 \%, 7.5 \%$, and $10 \%$ of customer sales. ${ }^{9}$ Although the analysis period extends over 20 years, customer-sited PV is added only during the first 10 years in order to capture "end effects" (i.e., impacts on utility costs and revenues that occur in years beyond those when PV is added).

The assumed PV deployment rates, particularly in the case of $10 \%$ penetration, are aggressive compared to both current penetration levels and even to projected penetration levels over the next decade, at both state and national levels. As of year-end 2013, electricity generation from customer-sited PV in the United States was equivalent to $0.2 \%$ of total U.S. retail electricity sales, and was as high as $4 \%$ of retail sales in Hawaii and $1-2 \%$ in the next two largest state solar markets (New Jersey and California). Current penetration rates for individual utilities, or for residential customer classes, may be higher. In Hawaii, penetration of customersited PV has reached $5.1 \%$ to $6.0 \%$ of retail sales among the three investor-owned utilities, and $10-15 \%$ for residential customer classes. Outside of Hawaii, the highest utility-level penetration rates are in California, where total customer-sited PV generation has reached 2.3\% of total retail sales (and 3.0\% of residential retail sales) in Pacific Gas \& Electric's service territory.

Projecting future growth in customer-sited PV is a highly speculative exercise. If one were to simply extrapolate average growth rates from the past five years, customer-sited PV penetration in 10 years would reach $0.8 \%$ of total U.S. retail electricity sales, and 3-5\% in the

\footnotetext{
${ }^{9}$ In addition to customer-sited PV, some amount of utility-scale PV is also assumed for both of the two prototypical utilities.
} 
largest state markets (excluding Hawaii, which would reach 20\%). Projections from EIA's most recent Annual Energy Outlook anticipate lower growth in customer-sited PV, with total generation from end-use PV reaching roughly $0.6 \%$ of total U.S. retail electricity sales over 10 years (EIA 2014), while forecasts from GTM and SEIA project slightly faster growth, with residential and commercial PV penetration reaching almost $0.8 \%$ of U.S. retail sales in just four years, by 2017 (GTM/SEIA 2014). As a final point of comparison, customer adoption modeling conducted for the SunShot Vision study, which considered a 75\% reduction in PV costs from 2010 to 2020, projected 3\% penetration of customer-sited PV in the Northeast (or 1-8\% among individual states in the region) and 7\% penetration in the Southwest (with penetration levels of 3$11 \%$ among individual states) by 2030 (DOE 2012).

\subsubsection{Impacts of customer-sited PV on retail sales and peak demand}

The utilities' retail sales and peak demand with and without customer-sited PV are shown in Figure 2 for the SW and NE utilities, under the 10\% PV penetration scenario. Throughout this analysis, we assume that all customer-sited PV is net-metered, with no binding limits on the amount of excess generation that can be carried over from billing period to the next. PV generation therefore reduces sales on a one-for-one basis; the difference between retail sales with and without PV thus grows proportionally with the linear growth in PV penetration over the first 10 years and then remains constant thereafter. PV generation does not, however, reduce peak demand on a one-for-one basis, but rather each $\mathrm{kW}$ of PV capacity reduces customer peak demand by less than one $\mathrm{kW}$, because the timing of maximum PV output does not coincide perfectly with customer peak demand. Moreover, the marginal impact of PV on peak demand declines as PV penetration levels grow over the first 10 years, as the timing of the net system peak progressively shifts to early evening periods with lower solar power generation. For 
simplicity, we assume that the reduction in aggregate customer billing demand from PV is equivalent to the reduction in utility-wide peak demand. ${ }^{10}$

\subsubsection{Impacts of customer-sited PV on utility costs and collected revenues}

The impact of customer-sited PV on utility costs (i.e., the revenue requirement) is a function of the changes in retail sales and peak demand described above, as well as a variety of other assumptions. The manner in which those cost impacts are modeled differs somewhat between the two prototypical utilities. For the purpose of explaining how customer-sited PV affects revenue requirements, however, it is useful to describe the impacts in terms of the underlying changes to generation-related costs and transmission and distribution (T\&D) costs

For the vertically integrated SW Utility, reductions in generation costs due to customersited PV are associated with reductions in fuel costs and purchased power costs, as well as the deferral of generation investments (including O\&M costs associated with those deferred generation investments). ${ }^{11}$ Fuel and purchased power costs, and the change in those costs due to customer-sited PV, are based on simplified dispatch logic. ${ }^{12}$ Deferrals of peaking plants (e.g., combustion turbines) are based on the number of years it takes before the peak demand with PV

\footnotetext{
${ }^{10}$ In practice, customer peak demand used for billing of demand charges is often not the same as the customer's coincident peak demand. However, given the complexity and variety of demand charge structures, and limitations of the model, we make the simplifying assumption that the change in aggregate billing demand is equal to the change in utility peak demand.

${ }^{11}$ We do not include any explicit "integration costs" associated with short-term variability and uncertainty of PV, though we do account for a decline in its capacity credit and energy value with increased penetration. The costs of short-term variability and uncertainty have been reported to be less than 0.5 cents/kWh of renewable generation for APS (B\&V 2012, Mills et al. 2013) and are therefore of secondary importance. Accounting for these integration costs would thus lead to a slight increase in estimated rate impacts of customer-sited PV, but no change to earnings and ROE, given that they consist of fuel costs that are passed through directly to customers in the FAC.

${ }^{12}$ Our financial model does not use an economic dispatch approach. As such, it is unable to capture certain impacts to wholesale or bi-lateral market prices that may impact utility revenues. Economic dispatch models might also produce different results in terms of timing of new investments, since they take into account different factors to "trigger" new generation.
} 
reaches the level of peak demand without PV for the year when the decision to build the generator would otherwise occur (see Figure 3). Similarly, deferrals of plants built primarily to supply energy (e.g., combined cycle gas turbines) are based on the number of years it takes before the sales with PV reaches the level of sales without PV for the year when the decision to build the generator would otherwise occur. Deferral of generation investment leads to reductions in depreciation costs, interest expenses (i.e., cost of debt to finance the generating plant), utility shareholder returns on the capital investment, and taxes (assessed on the shareholder returns).

In addition to deferral of utility-owned generation, customer-sited PV also reduces market purchases of energy and capacity to meet residual load needs, as well as PPAs with renewable generators required to meet the utility's RPS obligation. ${ }^{13}$ Those cost reductions are included within the model as purchased power costs. The reduction in RPS compliance costs occurs because customer-sited PV is reducing retail sales, not because it is being counted directly towards RPS obligations.

In contrast to the SW Utility, the NE Utility does not own generating assets and is assumed to purchase all of its energy and capacity needs through wholesale contracts. Thus, generation-related costs reduced by the addition of PV consist entirely of purchased power costs for energy and capacity. For RPS compliance, the NE Utility purchases fewer renewable energy credits to meet the RPS with PV than without PV, based on the retail sales reduction.

Note also that the impacts of PV on generation-related costs are based on reductions in sales and peak demand at the bulk power system level. Since customer-sited PV is located at the customer premises, reductions in sales and peak demand at the bulk power system level are greater than at the customer level due to avoided T\&D losses. For the SW Utility, T\&D losses

\footnotetext{
${ }^{13}$ A portion of the SW Utility's RPS obligation is assumed to be met with utility-owned renewable generation facilities; however, renewable PPAs are assumed to be the marginal RPS resource.
} 
are assumed to be $7 \%$ and $15 \%$ for retail sales and peak demand, respectively, and for the NE Utility, are assumed to be $4.1 \%$ and $8 \%$, respectively. ${ }^{14}$

Our results also show impacts of customer-sited PV on T\&D costs, based on our assumptions about the prototypical utilities and how they are represented in the financial model, but note in advance that this is a topic of substantial uncertainty and disagreement, and for that reason it is one key element explored within the sensitivity analysis.

For the SW Utility, T\&D capital costs are modeled as non-generation capital investments, and a fraction of those investments $(20 \%)$ is assumed to be proportional to growth in peak demand on the T\&D system. In the base-case, we assume that PV reduces peak demand at the T\&D level by $20 \%$ of the reduction in peak demand at the bulk power level. The corresponding reductions in $T \& D$ peak demand growth thereby reduce growth-related non-generation capital investments, resulting in reductions in depreciation expenses, shareholder returns on those investments, interest expenses, and taxes. For the base-case analysis, we assume therefore that customer-sited PV leads to a net reduction in distribution system capital expenses. Within the sensitivity analyses, however, we consider a case in which distribution costs increase as a result of PV.

For the NE Utility, the model treats transmission costs differently than distribution costs. The NE Utility does not own transmission facilities, but rather purchases transmission service from a regional transmission operator (ISO-NE) and passes those costs through to customers via a transmission access charge. Transmission charges are included in the model as a portion of purchased power costs and are calculated based on the average monthly peak demand of the utility. We assume that customer-sited PV reduces average monthly peak demand by $20 \%$ of the

\footnotetext{
${ }^{14}$ Losses for peak demand are greater than average losses due to the non-linear relationship between load levels and losses (Lazar and Baldwin 2011).
} 
reduction in annual peak demand, leading to corresponding reductions in the portion of purchased power costs associated with transmission access charges. ${ }^{15}$ In contrast, the NE Utility does own and operate distribution facilities, and distribution costs are therefore modeled as a capital investment, some portion of which is growth related (assumed to be 33\%). Similar to the approach used to model T\&D cost impacts for the SW Utility, the addition of PV reduces growth-related distribution system capital expenses for the NE Utility, leading to corresponding reductions in returns on ratebase, depreciation expenses, interest, and taxes.

Given the modeled relationships described above, the total reductions in utility costs (i.e., revenue requirements) resulting from customer-sited PV in the base-case analysis are shown in Figure 4, with further details on the underlying source of cost reductions listed in Table 1. For the SW Utility, customer-sited PV reduces total utility costs over the 20 -year analysis period by $\$ 0.7$ B (1.3\% of total utility costs) under $2.5 \%$ PV penetration and by $\$ 2.2 \mathrm{~B}$ (4.0\% of total utility costs) under $10 \%$ PV penetration, compared to a case without any customer-sited PV. Similarly, for the NE Utility, the cost reductions range from $\$ 0.8 \mathrm{~B}$ (1.5\% of total utility costs) at $2.5 \% \mathrm{PV}$ penetration to $\$ 2.3 \mathrm{~B}$ ( $4.5 \%$ of total utility costs) at $10 \% \mathrm{PV}$ penetration. The composition of the cost reductions differs significantly between the two utilities due to differences in the two utilities' physical and operating characteristics, with important implications for the shareholder and ratepayer impacts, as discussed below.

All customer-sited PV within our analysis is net-metered under the same retail rates applicable to other customers, and without any PV-specific charges (e.g., additional fixed charges or standby charges for PV customers). The impacts of customer-sited PV on total utility collected revenues are thus a function of changes in billing determinants and in the rates for each

\footnotetext{
${ }^{15}$ The $20 \%$ assumption is based on an analysis of hourly load and PV generation in the Northeast over the span of one year.
} 
billing determinant caused by PV. The change in billing determinants is simply the reduction in retail sales and peak demand, while the change in rates reflects the net effect of customer-sited PV on test-year costs (i.e., revenue requirements) and billing determinants used within each GRC.

Customer-sited PV reduces revenues related to both fuel costs and non-fuel costs. ${ }^{16}$ For the purpose of understanding how these revenue impacts ultimately translate to impacts on shareholder ROE and earnings, it is most useful, however, to focus specifically on impacts to non-fuel revenues. To illustrate, Figure 5 compares reductions in non-fuel revenues under each $\mathrm{PV}$ penetration scenario to the corresponding reductions in non-fuel costs. In the case of the SW Utility, the impacts on revenues and costs are roughly equivalent under the $2.5 \%$ PV penetration scenario. At higher PV penetration levels, however, reductions in non-fuel revenues exceed reductions in non-fuel costs. This occurs, in part, because of the declining marginal value of PV as penetration levels increase. For the NE Utility, the divergence between reductions in non-fuel revenues and non-fuel costs is substantially wider. This is because of a greater assumed growth rate in non-fuel O\&M costs for the NE Utility and the assumption that those costs are not reduced as a result of customer-sited PV.

\subsubsection{Reduction in utility achieved ROE and earnings}

Under our base-case assumptions, customer-sited PV leads to a reduction in the prototypical utilities' achieved ROE. This occurs because, as discussed in the preceding section, PV reduces collected non-fuel revenues by a greater amount than non-fuel costs (i.e., "revenue

\footnotetext{
${ }^{16}$ Throughout this paper, we distinguish between two broad categories of costs: fuel costs and non-fuel costs. When used within the context of this distinction, "fuel costs" refers to all costs that are fully passed through to customers, via annually adjusted FAC charges. These include (as applicable, depending upon the utility): fuel costs for utility-owned generation, all purchased power costs associated with long-term contracts and short-term purchases of energy and capacity, and transmission access costs. "Non-fuel costs" simply refers to all remaining utility costs, which include both fixed and variable costs. These costs are recovered through retail rates established in GRCs based on test-year costs and billing determinants.
} 
erosion effect"), which in turn reduces earnings and thereby reduces ROE. For the SW Utility, achieved average ROE over the first 10 years of the analysis period is 2 basis points lower at 2.5\% PV penetration and 23 basis points lower at $10 \% \mathrm{PV}$ penetration than it is without $\mathrm{PV}$ (see Figure 6). ${ }^{17}$ These basis point reductions represent, in relative terms, a $0.3 \%$ to $2.9 \%$ reduction in average utility shareholder returns over the first 10 years. For the NE Utility, the ROE impacts are somewhat more substantial, with a 32 basis point $(4.7 \%)$ reduction at $2.5 \%$ PV penetration and a 125 basis point $(18 \%)$ reduction at $10 \%$ PV penetration, relative to the no-PV case.

The larger ROE impacts for the NE Utility are due to two underlying factors. The first factor can be traced back to the greater assumed growth rate in non-fuel O\&M costs for the NE Utility, which in turn leads to a greater divergence between the impact of customer-sited PV on non-fuel revenues and non-fuel costs (i.e., the dynamic discussed in section 3.1.2). The other key factor underlying the difference in ROE impacts between the two utilities is the proportionally smaller ratebase (compared to retail sales) of the wires-only NE Utility, as that utility does not own generation assets. A given reduction in earnings will therefore have a proportionately larger ROE impact for the NE Utility, as ROE is equal to earnings divided by the ratebase equity.

Customer-sited PV may reduce shareholder earnings through two separate mechanisms. First, it can do so if it reduces utility revenues by a greater amount than it does costs (i.e., the "revenue erosion effect" that also drives the impacts on ROE). Second and separately, customersited PV may also diminish future earnings opportunities, by reducing or deferring capital

\footnotetext{
${ }^{17}$ The impacts of PV on achieved annual ROE are, in general, concentrated primarily within the initial 10 years of the analysis period and are more readily interpretable for that timeframe. Thus, throughout the remainder of this paper, our discussions of ROE impacts focus solely on the first 10 years of the analysis period (though we continue to discuss earnings and rate impacts over the full 20-year period).
} 
investments that would otherwise contribute to the utility's ratebase (which we term the "lost earnings opportunity effect").

Additional earnings erosion occurs over the latter half of the 20 -year analysis period, as deferral of capital investments continues beyond the initial 10-year period when customer-sited PV is installed. These "end-effects" are particularly pronounced in the case of the SW Utility, where PV results in deferral of generation plants in the latter 10 years (see Figure 7). Thus, at $10 \% \mathrm{PV}$ penetration, achieved earnings over the full 20 -year analysis period are $\$ 528 \mathrm{M}(8.1 \%)$ lower than with no PV, compared to the $\$ 193 \mathrm{M}$ (5.7\%) reduction over the first 10 years, as noted above. For the NE Utility as well, additional earnings erosion occurs in years 11-20, though to a much more limited extent, given that the utility does not own generation and thus the only deferred capital expenditures are for distribution system investments. At $10 \%$ PV penetration, for example, achieved earnings by the NE Utility are reduced by $20 \%$ in the first ten-years, but only $15 \%$ over the full 20 years of the analysis period (see Figure 8 ).

As with the impact of PV on achieved ROE, we see that the impact of PV on earnings, in percentage terms, is larger for the NE Utility than for the SW Utility, though the difference between the two utilities is not as large. As noted, the impact of customer-sited PV on achieved earnings is the combined result of the "revenue-erosion effect" (associated with the disproportionately larger reduction in collected revenues than in utility costs) and the "lost earnings opportunity" effect (associated with the deferral of capital expenditures). The former effect is larger for the NE Utility than for the SW Utility; as discussed previously, this is due to the larger assumed growth in non-fuel O\&M costs for the NE Utility and the assumption that customer-sited PV does not reduce those costs. In contrast, the latter "lost earnings opportunity" effect is larger for the SW Utility, given that the SW Utility owns generation plants that are 
deferred by customer-sited PV. On net, though, the difference between the two utilities is greater with respect to the revenue erosion effect, and thus the earnings impacts are slightly greater for the NE Utility.

\subsubsection{Increase in customer average all-in retail rates}

Within the timeframe of our analysis, customer-sited PV impacts average, all-in retail rates in two, inter-related ways. First, it impacts the retail rates set within each GRC through the net result of reductions in the test-year utility costs and billing determinants used to establish rates. Under our base-case assumptions customer-sited PV generally reduces utility costs by less than it reduces retail sales. As a result, average retail rates established through each GRC increase with the addition of customer-sited PV. That particular dynamic is dependent on a variety of assumptions related to the ability of customer-sited PV to reduce utility cost, some of which are explored later within the sensitivity analysis. Second, customer-sited PV impacts average rates in the years between GRCs, though this effect is simply a mathematical artifact. Average rates are, by definition, equal to total collected revenues divided by total retail sales. Among customers with PV, the net-metered PV reduces both the revenues received from those customers (the numerator) and their retail sales (the denominator), but the reductions in revenues are necessarily smaller, given that some portion of revenues are derived from fixed customer charges (which are unaffected by PV) and demand charges (which are only marginally affected by PV).

\subsection{Sensitivity Analysis}

\subsubsection{Magnitude of shareholder and ratepayer impacts are dependent on utility circumstances}


The base case results reflect a variety of assumptions about the two prototypical utilities. Actual conditions faced by U.S. utilities, however, vary considerably and many of the assumptions employed within our base case analysis relate to future trends that are subject to significant uncertainty. In order to examine how the impacts of customer-sited PV on utility shareholders and ratepayers may depend on assumptions about our prototypical utilities' operating and regulatory environments, we performed a series of sensitivity analyses (see Table 2). These alternate cases represent many of the most significant, though by no means all, potential sources of uncertainty and variation among utilities. Moreover, even in regard to some of the sensitivities examined, some utilities may exhibit even more extreme divergence from our base-case assumptions. As such, our purpose here is not to bound the potential range of impacts, but rather to illustrate a number of key themes and considerations relevant to gauging the possible magnitude of those impacts.

Two important structural features of the sensitivity analysis must be noted. First, for each sensitivity case, we characterize the impacts of customer-sited PV under the $10 \%$ PV penetration trajectory (i.e., where customer-sited PV ramps up to $10 \%$ of total retail sales over 10 years), ignoring the lower penetration levels considered within the base case analysis. We focus on this higher PV penetration in order to more clearly highlight and compare the relative degrees of sensitivity across the various cases examined, but acknowledge again that this is an arguably aggressive trajectory compared to current penetration levels and growth rates for most states and utilities. Were lower PV penetration levels assumed, the impacts of PV would be smaller and the ranges across sensitivity cases would be narrower, but the fundamental results would be qualitatively the same. Second, each sensitivity case varies a single assumption or small number 
of assumptions. In reality, however, a more complex set of interactions and interdependencies may exist among various modeling assumptions (e.g., between rate design and load growth).

The shareholder and ratepayer impacts from customer-sited PV are directionally consistent across the sensitivity cases (see Figure 9). Namely, with one exception, customersited PV results in a decrease in achieved shareholder earnings and ROE and an increase in all-in average retail rates, regardless of assumptions about the utility operating and regulatory environment. The magnitude of those impacts, however, varies considerably across the cases, demonstrating that the financial impacts from customer-sited PV critically depend on the specific conditions of the utility. For the SW Utility, the reduction in achieved earnings from customersited PV ranges from roughly $5 \%$ to $13 \%$, while the reduction in achieved ROE ranges from $1 \%$ to $9 \%$, and the increase in average rates ranges from roughly $0 \%$ to $4 \%{ }^{18}$ The impacts for the NE Utility are even more varied, ranging from a $6 \%$ to $41 \%$ reduction in earnings, a $5 \%$ to $38 \%$ reduction in ROE, and a $1 \%$ to $4 \%$ increase in average rates. The greater sensitivity in ROE and earnings impacts for the NE Utility are due to the fact that its ratebase and earnings are much smaller, relative to its total revenue requirements, and thus variations in the absolute level of those metrics lead to relatively large percentage changes.

\subsubsection{Financial impacts also vary based on assumptions about value of $P V$}

As discussed throughout, the financial impacts of customer-sited PV on utility shareholders and ratepayers are driven, in part, by the associated impacts on utility costs (i.e., the avoided cost "value of PV"). Among the various sources of cost reductions, avoided generation capacity and T\&D capacity costs are arguably the source of greatest uncertainty and

\footnotetext{
${ }^{18}$ Throughout this section, we focus on the earnings and rate impacts over the full 20-year analysis period in order to capture any "end-effects" associated with reduced capital expenditures in the latter decade, but focus on ROE impacts over only the first 10 years, during which the impacts are most pronounced and interpretable.
} 
disagreement (see Hansen et al. 2013). In the financial model used for the present analysis, the impacts of customer-sited PV on generation capacity and T\&D capacity costs are driven by several parameters that define the "capacity credit" of customer-sited PV at the bulk power system level and on the distribution system. For the SW Utility, capacity credit assumptions affect the deferral of generation capacity investments as well as reductions in growth-related capital expenditures for $\mathrm{T} \& \mathrm{D}$, while for the NE Utility, they affect the cost reductions associated with market purchases of generation and transmission capacity as well as reductions in growthrelated capital expenditures for the distribution system.

We developed a set of alternate sensitivity cases to better understand the sensitivity of shareholder and ratepayer impacts from customer-sited PV to assumptions related to its capacity value and avoided T\&D costs. These sensitivity cases involved modifying a number of parameters in the model (see Table 2), based on ranges for several of these parameters that exist in the literature (Hoff et al. 2008). With respect to the capacity credit at the bulk power level, in the High Value of PV scenario we slow the rate of decline of the capacity credit with increasing PV penetration, such that later vintages of PV installations contribute to a greater extent to reducing peak demand, while in the Low Value of PV scenario we assume a lower capacity credit for even early vintages of customer-sited PV. The scenarios also involve varying assumptions about the percentage of the capacity credit at the bulk power level that is then applied at the T\&D level, where in the Low Value of PV case we assume $0 \%$ capacity credit for the purpose of T\&D deferrals. Finally, in the Low Value of PV scenario, we also increase the growth rate for nongeneration capital investments in conjunction with $\mathrm{PV}$, to represent the possibility that integration costs for customer-sited PV could result in a net increase in distribution system expenditures. 
As shown in Figure 10, the impacts of customer-sited PV on shareholder earnings vary widely under these different assumptions related to the value of PV. Under the high value of PV scenarios, customer-sited PV results in greater reductions in capital expenditures than in the base case and thus, as a result, there are greater lost future earnings opportunities for the utility, exacerbating the earnings impacts. Under the low value of PV scenarios, the earnings impacts are correspondingly more moderate, as fewer capital expenditures are deferred. The rate impacts from customer-sited PV are also quite sensitive to the value of PV, but move in the opposite direction: increasing under the low value of PV scenario (whereby customer-sited PV is less effective at reducing utility costs) and decreasing under the high value of PV scenario. Of some note, customer-sited PV leads to a slight reduction in average retail rates for the SW Utility under the high value of PV scenario. This occurs because the reduction in utility costs from PV exceeds the reduction in utility revenues.

\section{Discussion}

Even at penetration levels substantially higher than exist today, the impact of customersited PV on average retail rates may be relatively modest. We consider customer-sited PV penetration levels that ramp up to $10 \%$ of retail sales in 2022 , compared to current rates of $1-2 \%$ in high-penetration states and a U.S. average of $0.2 \%$. For the two prototypical utilities considered within our analysis, this PV deployment trajectory leads to roughly a $3 \%$ increase in average, all-in retail rates under our base-case set of assumptions, and to a $0 \%$ to $4 \%$ rate increase across the various sensitivity cases tested. These results should, of course, be considered in light of the nature and scope of our analysis - for example, that they are modeled results based on certain assumptions about the prototypical utilities and about how distributed 
PV impacts costs and revenues, and that the analysis considers the impact of distributed PV in isolation from other factors that may simultaneously place downward pressure on sales and/or upward pressure on rates.

Compared to the impacts on ratepayers, the impacts of customer-sited PV on utility shareholders are potentially much more pronounced. In the case of the two prototypical utilities in our analysis, for example, shareholder earnings fell by $8 \%$ for the SW utility and by $15 \%$ for the NE utility under the base-case assumptions and at 10\% PV penetration, but fell by as much as $13 \%$ and $41 \%$ (for the SW utility and NE utility, respectively) under certain other conditions. While our analysis is focused on the impacts to utility shareholders and ratepayers from customer-sited PV in isolation, we note that the financial health of regulated utilities may be impacted by factors beyond distributed solar. Some of these factors may pose further negative financial impacts (e.g., costs of new environmental regulations), whereas others may present future earnings opportunities that would offset some of the impacts from customer-sited PV (e.g., new distribution system investment to accommodate smart grid systems). 


\section{Conclusions and Policy Implications}

The findings from this analysis suggest several policy implications. First, our analysis suggests that distributed PV is unlikely, on its own, to lead to rate impacts of such a magnitude as to dramatically alter the customer-economics of PV, and to thereby result in a "death spiral" of departing load and concomitant rate increases. To the extent that efforts to mitigate the rate impacts of customer-sited PV are still warranted, utilities, policymakers, and solar stakeholders likely have sufficient time to address these concerns in a measured and deliberate manner.

Second, the potential magnitude of these impacts - especially among wires-only utilities or other utilities with a relatively small ratebase - may create more immediate pressure on utilities to address shareholders concerns about the erosion of profits caused by customer-sited PV. However, as shown in the analysis, these impacts are highly dependent upon the specifics of the utility operating and regulatory environment, and it will therefore be important for policymakers and others to consider the particular conditions of any individual utility when assessing the possible impacts of customer-sited PV on the utility's shareholders. There are options for regulators and utilities to mitigate revenue erosion and lost earnings opportunities and the associated increases in average retail rates. ${ }^{19}$ Furthermore, some states are considering more fundamental changes to regulatory models (e.g., performance-based ratemaking) that may also serve to mitigate misalignments between utility and customer interests.

Finally, the high degree of sensitivity of shareholder and ratepayer impacts to the value of $\mathrm{PV}$ - and the divergent implications of that sensitivity for shareholders versus ratepayers - has several implications. First, it reinforces the importance of efforts aimed at improving the data

\footnotetext{
${ }^{19}$ Mitigation options are discussed in a companion paper (Satchwell et al. 2014b).
} 
and methods for estimating the value of PV. Better understanding of the capacity value and avoided T\&D costs of PV improves estimates of the impact of PV on shareholders and ratepayers. Second, it shows that, even within the somewhat limited range of assumptions about the value of PV considered here, it is conceivable that customer-sited PV could result in virtually no increase or perhaps even a slight decrease in average retail rates. And third, the results are suggestive of the potential to mitigate the ratepayer impacts of customer-sited PV through deployment strategies that seek to maximize its capacity deferral value (e.g., by placing PV in locations or with orientations that maximize its capacity credit). Policymakers must recognize, however, that such strategies may run counter to the financial interests of utility shareholders, whose earnings would be further eroded by greater reductions in capital expenditures.

\section{Acknowledgements}

This work was supported by the Office of Energy Efficiency and Renewable Energy (Solar Energy Technologies Office) of the U.S. Department of Energy under Contract No. DEAC02-05CH11231. We would particularly like to thank Elaine Ulrich, Kelly Knutsen, Christina Nichols, and Minh Le of the U.S. Department of Energy (US DOE) for their support of this project, and for supporting development of the financial model used in this study, we would like to thank Larry Mansueti (US DOE). 


\section{References}

American Public Power Association (APPA). 2014. Solar Photovoltaic Power: Assessing the Benefits \& Costs. Washington, D.C.: American Public Power Association.

Beach, T., and McGuire, P. 2013. Evaluating the Benefits and Costs of Net Energy Metering in California. Prepared for Vote Solar. Berkeley, CA: Crossborder Energy.

Black \& Veatch (B\&V). 2012. Solar Photovoltaic Integration Cost Study, November.

Borenstein, S. 2013. Rate design wars are the sound of utilities taking residential PV seriously. Berkeley, CA: University of California Haas School of Business, Energy Economics Exchange.

Bradford, T. and A. Hoskins. 2013. Valuing Distributed Energy: Economic and Regulatory Challenges. Working paper for Princeton Roundtable. Princeton University.

Cappers, P., C. Goldman, M. Chait, G. Edgar, J. Schlegel, and W. Shirley. 2009. Financial Analysis of Incentive Mechanisms to Promote Energy Efficiency: Case Study of a Prototypical Southwest Utility. LBNL-1598E. Berkeley, CA: Lawrence Berkeley National Laboratory.

Cappers, P., and C. Goldman. 2009a. Empirical Assessment of Shareholder Incentive Mechanisms Designs under Aggressive Savings Goals: Case Study of a Kansas "Super-Utility." LBNL-2492E. Berkeley, CA: Lawrence Berkeley National Laboratory.

Cappers, P., and C. Goldman. 2009b. Financial Impact of Energy Efficiency under a Federal Renewable Electricity Standard: Case Study of a Kansas "Super-Utility”. LBNL-2924E. Berkeley, CA: Lawrence Berkeley National Laboratory.

Cappers, P., A. Satchwell, C. Goldman, and J. Schlegel. 2010. Benefits and Costs of Aggressive Energy Efficiency Programs and the Impacts of Alternative Sources of Funding: Case Study of Massachusetts. LBNL-3833E. Berkeley, CA: Lawrence Berkeley National Laboratory.

Cappers, P., and C. Goldman. 2010. "Financial Impact of Energy Efficiency under a Federal Combined Efficiency and Renewable Electricity Standard: Case Study of a Kansas "SuperUtility."” Energy Policy 38 (8): 3998-4010.

Cardwell, D. July 26, 2013. “On Rooftops, a Rival for Utilities.” The New York Times.

Cliburn, J.K. and J. Bourg. 2013. Ratemaking, Solar Value and Solar Net Energy Metering-A Primer. Washington, D.C.: Solar Electric Power Association.

Dumoulin-Smith, J., M. Sanghavi, and S. Chin. 2013. "The Thousand Distributed Cuts Coming." Research Note: UBS Investment Research, U.S. Utilities \& Renewables. September 20, 2013.

Energy + Environmental Economics (E3). 2013. California Net Energy Metering (NEM) Cost Effectiveness Evaluation. San Francisco, CA: Energy + Environmental Economics. 
Energy + Environmental Economics (E3). 2014. Nevada Net Energy Metering Impacts Evaluation. San Francisco, CA: Energy + Environmental Economics.

Energy Information Administration (EIA). 2014. Annual Energy Outlook 2014. DOE/EIA0383(2014). Washington, D.C.: U.S. Energy Information Administration.

Goldman Sachs Global Investment Research. 2013. A near-term decision on net metering in Arizona and what it means for Solar and Utilities.

Greentech Media (GTM) Research and Solar Energy Industries Association (SEIA). 2014. U.S. Solar Market Insight Report: 2013 Year-In-Review. GTM Research and Solar Energy Industries Association.

Hansen, L., V. Lacy, and D. Glick. 2013. A Review of Solar PV Benefit and Cost Studies. Boulder, CO: Rocky Mountain Institute.

Hoff, T., R. Perez, JP Ross, and M. Taylor. Photovoltaic Capacity Valuation Methods. Washington D.C.: Solar Electric Power Association, May 2008.

National Action Plan for Energy Efficiency (NAPEE). 2007. Aligning Utility Incentives with Investment in Energy Efficiency. Prepared by V. Jensen, ICF International.

Keyes, J., and K. Rabago. 2013. A Regulator's Guidebook: Calculating the Benefits and Costs of Distributed Solar Generation. Latham, NY: Interstate Renewable Energy Council, Inc.

Lazar, J., and X. Baldwin. 2011. Valuing the Contribution of Energy Efficiency to Avoided Marginal Line Losses and Reserve Requirements. Montpelier, VT: Regulatory Assistance Project.

Mills, A., A. Botterud, J. Wu, Z. Zhou, B. M. Hodge, and M. Heaney. 2013. Integrating Solar PV in Utility System Operations. Argonne, IL: Argonne National Laboratory, October.

Oliva, S., and I. MacGill. 2012. "Assessing the Impact of Household PV Systems on the Profits of All Electricity Industry Participants." Proceedings of the Institute of Electrical and Electronics Engineers (IEEE) Power and Energy Society General Meeting. San Diego, CA. July 26-27, 2012.

Satchwell, A., P. Cappers, and C. Goldman. 2011. "Carrots and Sticks: A Comprehensive Business Model for the Successful Achievement of Energy Efficiency Resource Standards." Utilities Policy 19: 218-225.

Satchwell, A., A. Mills, G. Barbose, R. Wiser, P. Cappers, and N. Darghouth. 2014a. Financial Impacts of Net-Metered PV on Utilities and Ratepayers: A Scoping Study of Two Prototypical U.S. Utilities. LBNL-XXXX. Berkeley, CA: Lawrence Berkeley National Laboratory.

Satchwell, A., A. Mills, and G. Barbose. 2014b. "Regulatory and Ratemaking Approaches to Mitigate Financial Impacts of Net-Metered PV on Utilities and Ratepayers." Energy Policy. Submitted. 
Solar Electric Power Association (SEPA). 2014. Utility Solar Market Snapshot: Solar Market Comes of Age in 2013. Washington D.C.: Solar Electric Power Association.

Stanton, T., and D. Phelan. 2013. State and Utility Solar Energy Programs: Recommended Approaches for Growing Markets. Report No. 13-07. Silver Spring, MD: National Regulatory Research Institute.

Tracy, R. May 2, 2013. "Solar-Regulation Tiffs Flare Across States: Fight Brewing in Lousiana Between Entergy, NRG Over Payments Could Lead to Less Investment in Renewables." Wall Street Journal.

United States Department of Energy (DOE). 2012. SunShot Vision Study. DOE/GO-1020123037. Washington D.C.: United States Department of Energy.

Figure captions:

Figure1. Simplified Representation of the Model and Calculation of Stakeholder Metrics

Figure 2. Utility Retail Sales and Peak Demand with and without PV Assuming 10\% PV Penetration in 2022

Figure 3. Illustration of the Peaker Generation Investment Logic with PV in the Model

Figure 4. Reduction in Utility Revenue Requirements with Customer-Sited PV

Figure 5. Reduction in Utility Non-Fuel Revenue Requirements (Costs) and Collected Revenues

Figure 6. Reduction in Achieved After-Tax ROE

Figure 7. Generation Investment Deferral for the SW Utility with 10\% PV

Figure 8. Reduction in Achieved After-Tax Earnings

Figure 9. Impacts of Customer-Sited PV across Sensitivity Cases

Figure 10. Sensitivity of PV Impacts to Value of Solar 
Table 1. Sources of Modeled Reductions in Utility Costs from Customer-Sited PV

\section{Cost Category}

Fuel \& Purchased

Power

O\&M

Depreciation

Interest on Debt

Return on Ratebase

Taxes

\section{SW Utility}

- Reduced fuel costs for utility-owned generation

- Reduced energy and capacity market purchases and PPAs

- Reduced RPS procurement costs

- Reduced losses

- Reduced O\&M due to deferred utilityowned generation

- Deferred utility-owned generation

- Reduced T\&D CapEx

\section{NE Utility}

- Reduced energy and capacity market purchases

- Reduced transmission access charges

- Reduced RPS procurement costs

- Reduced losses

- None

- Reduced distribution system CapEx
- Deferred utility-owned generation

- Reduced T\&D CapEx

- Reduced collected revenues
- Reduced distribution system CapEx

- Reduced collected revenues

Table 2. Sensitivity Cases

\section{Sensitivities}

Value of PV

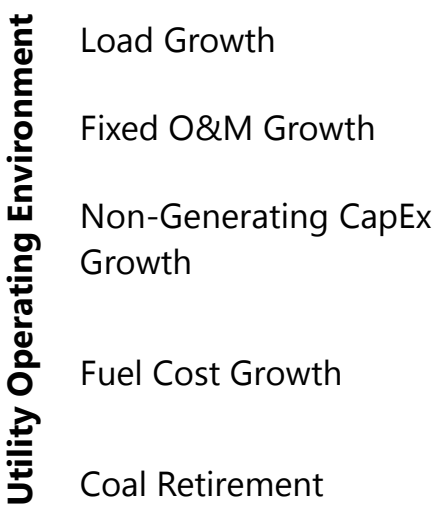

Utility-Owned Generation

Share

Utility-Owned Generation

\section{Description}

Higher/lower PV capacity credit and ability of $P V$ to offset non-generation capital expenditure (CapEx)

Higher/lower load growth

Higher/lower growth rate of fixed O\&M costs

Higher/lower growth rate of non-generation CapEx

Higher/lower growth rate of fuel costs or wholesale energy market prices

Early retirement of existing coal generation

Higher share of utility-owned generation
SW NE

Utility Utility 


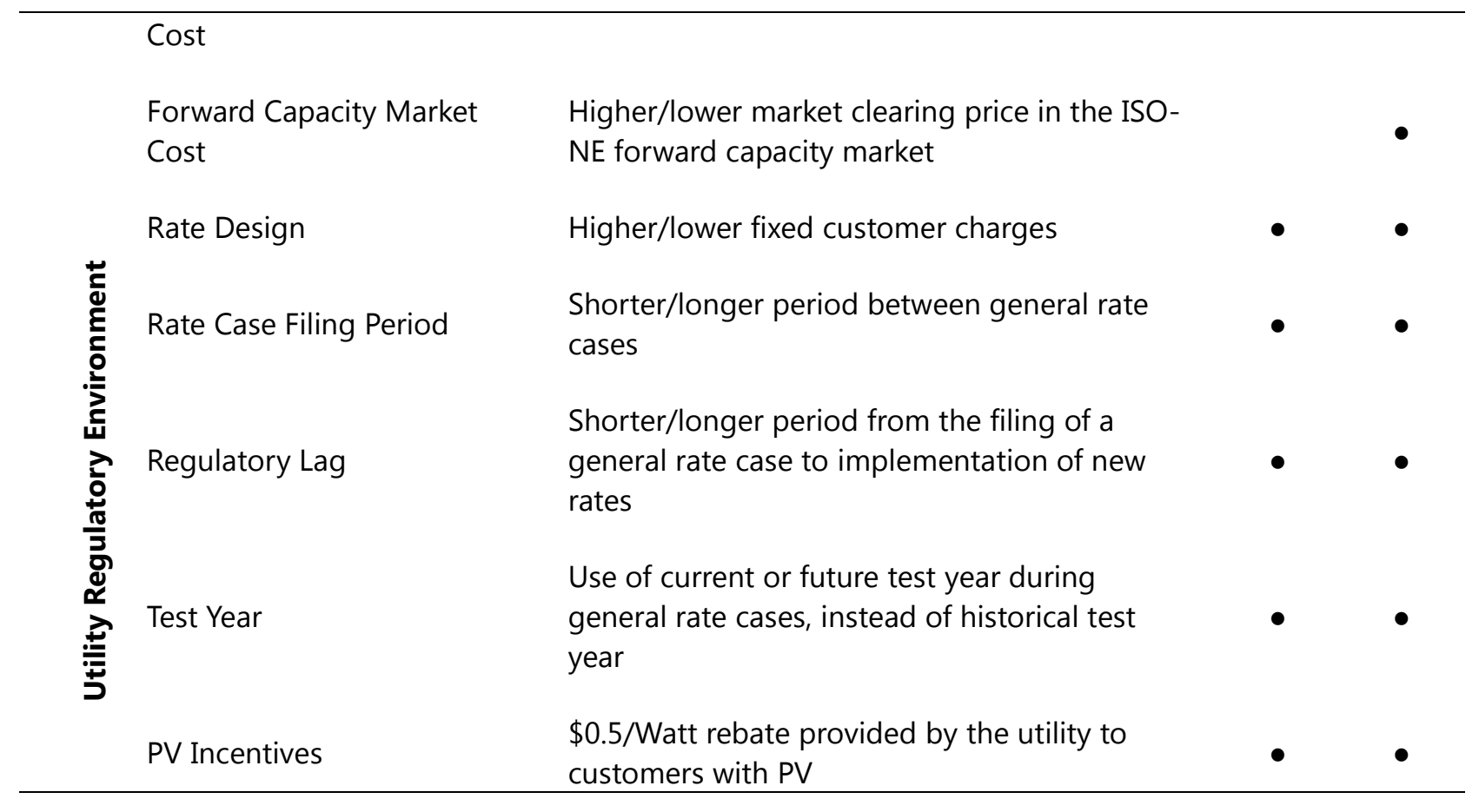




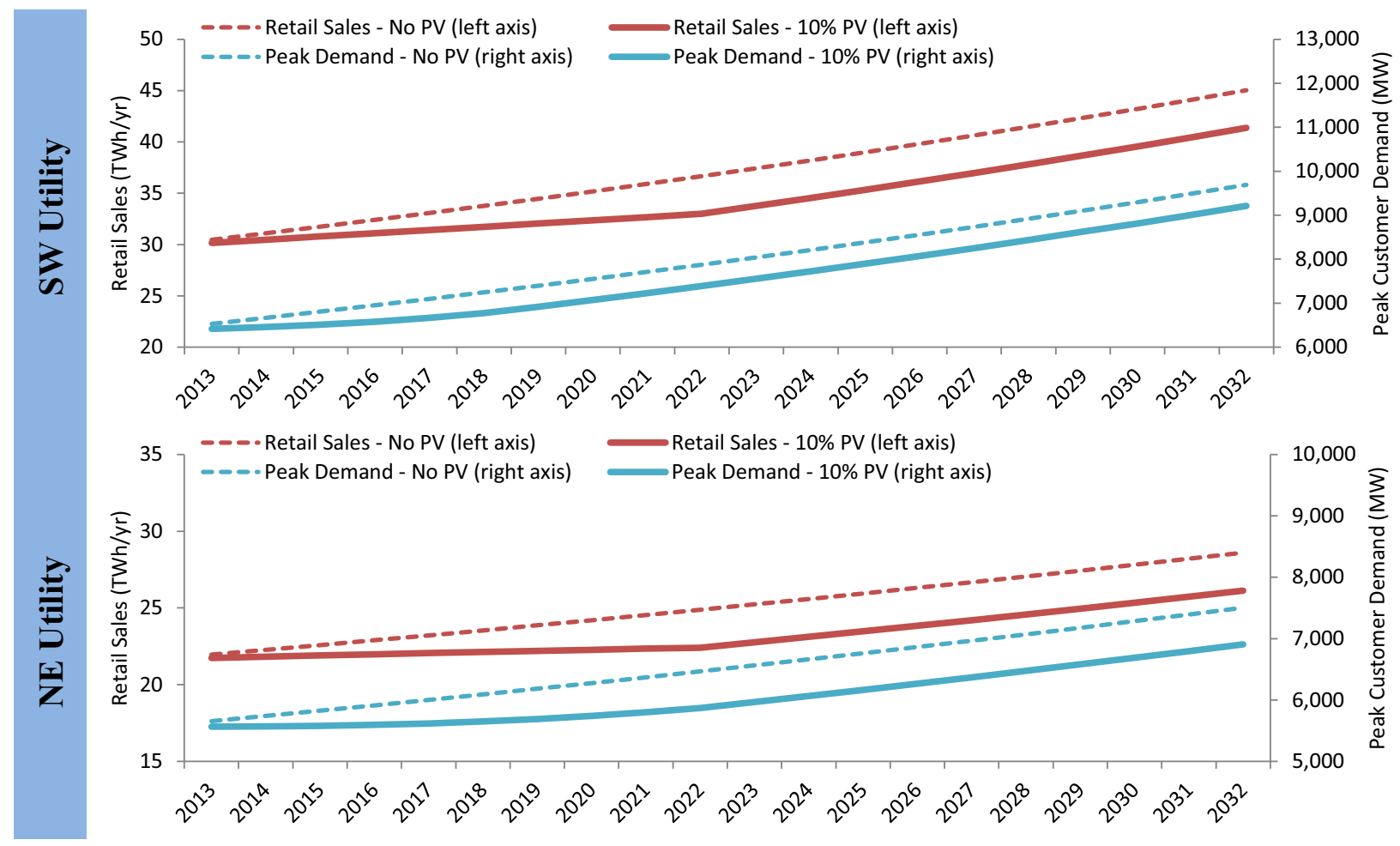

Figure 2. Utility Retail Sales and Peak Demand with and without PV Assuming 10\% PV Penetration in 2022 


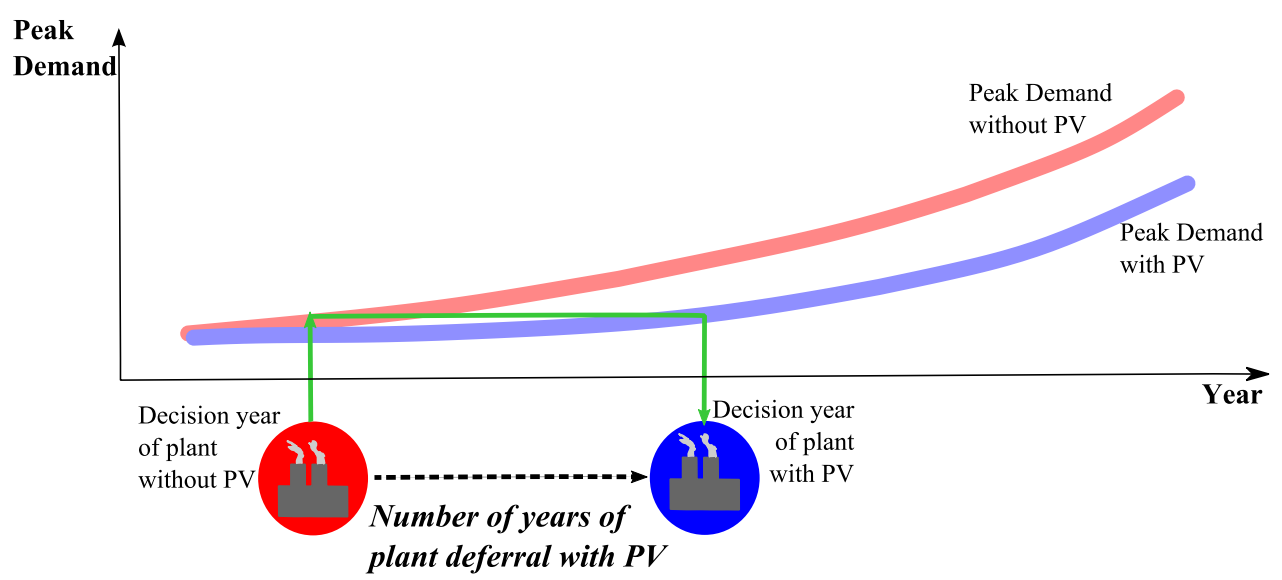

Figure 3. Illustration of the Peaker Generation Investment Logic with PV in the Model 


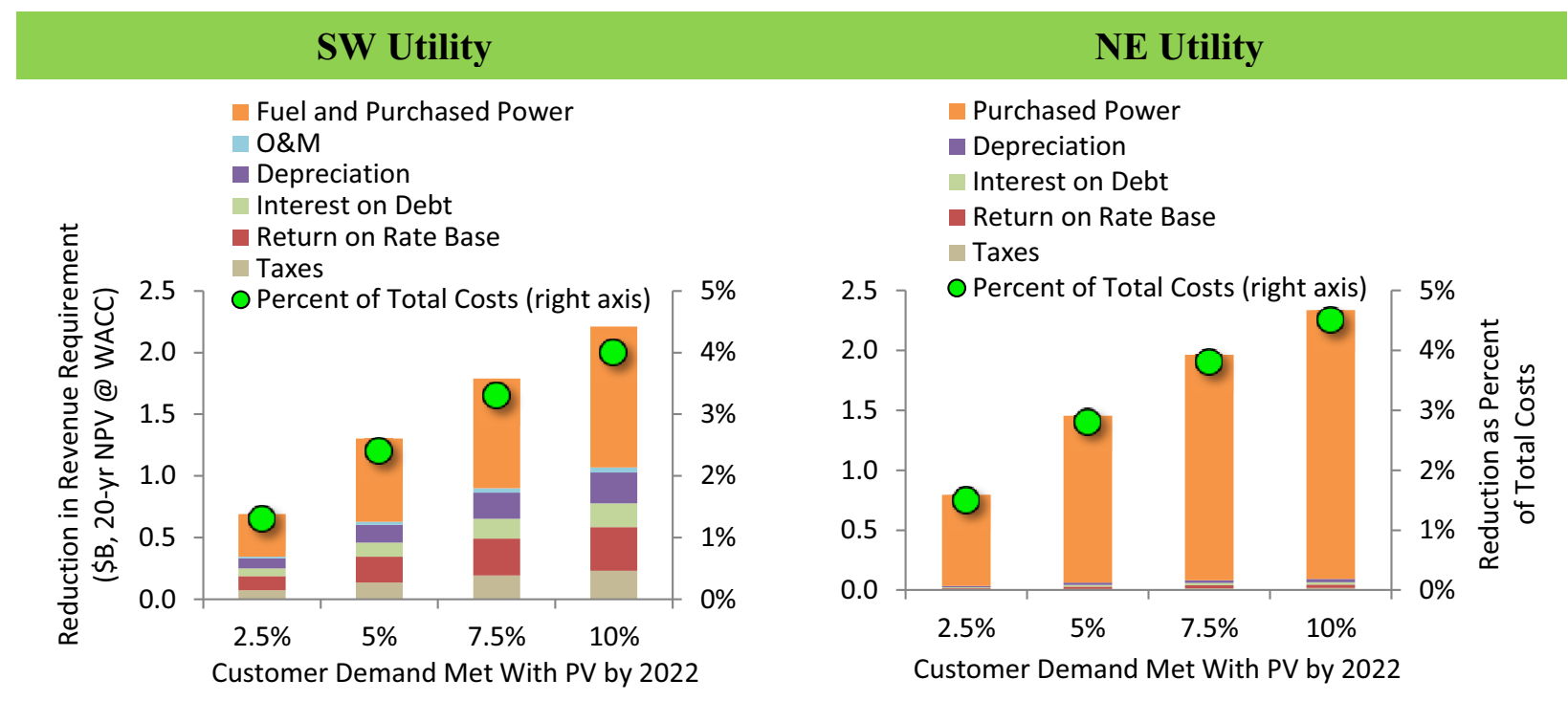

Figure 4. Reduction in Utility Revenue Requirements with Customer-Sited PV 


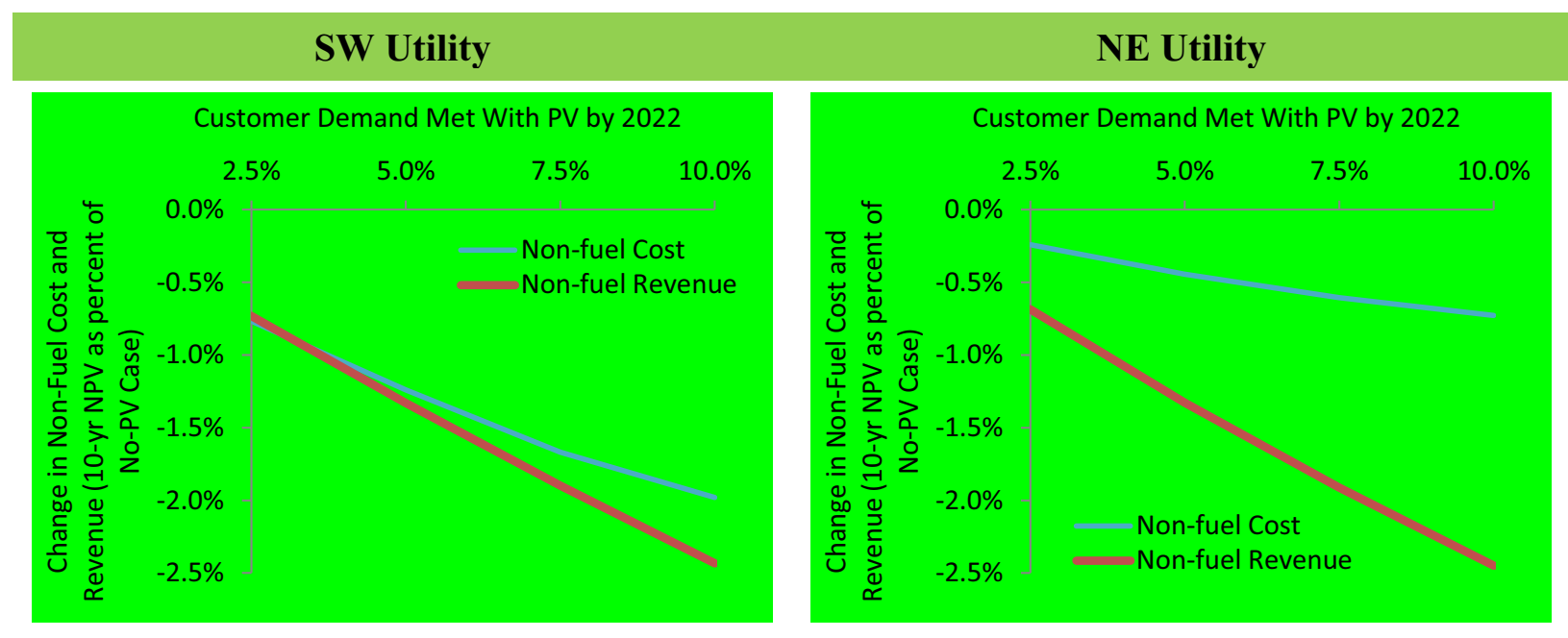

Figure 5. Reduction in Utility Non-Fuel Revenue Requirements (Costs) and Collected Revenues 


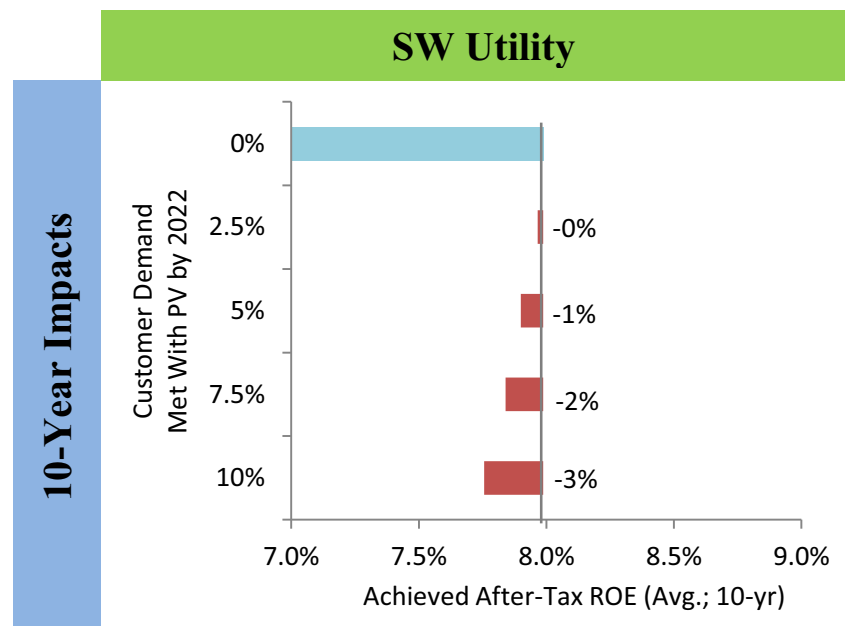

\section{NE Utility}
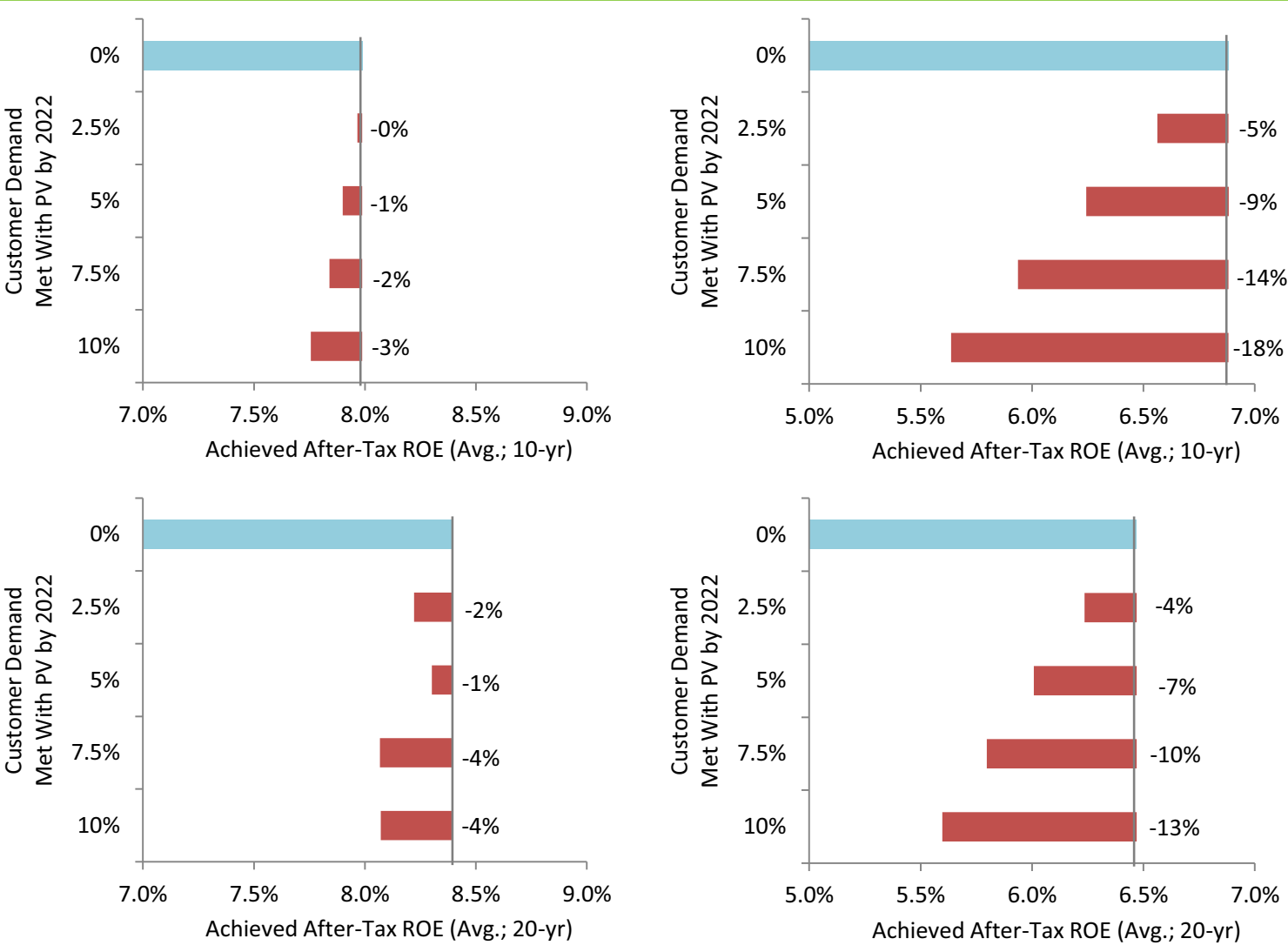

Figure 6. Reduction in Achieved After-Tax ROE 


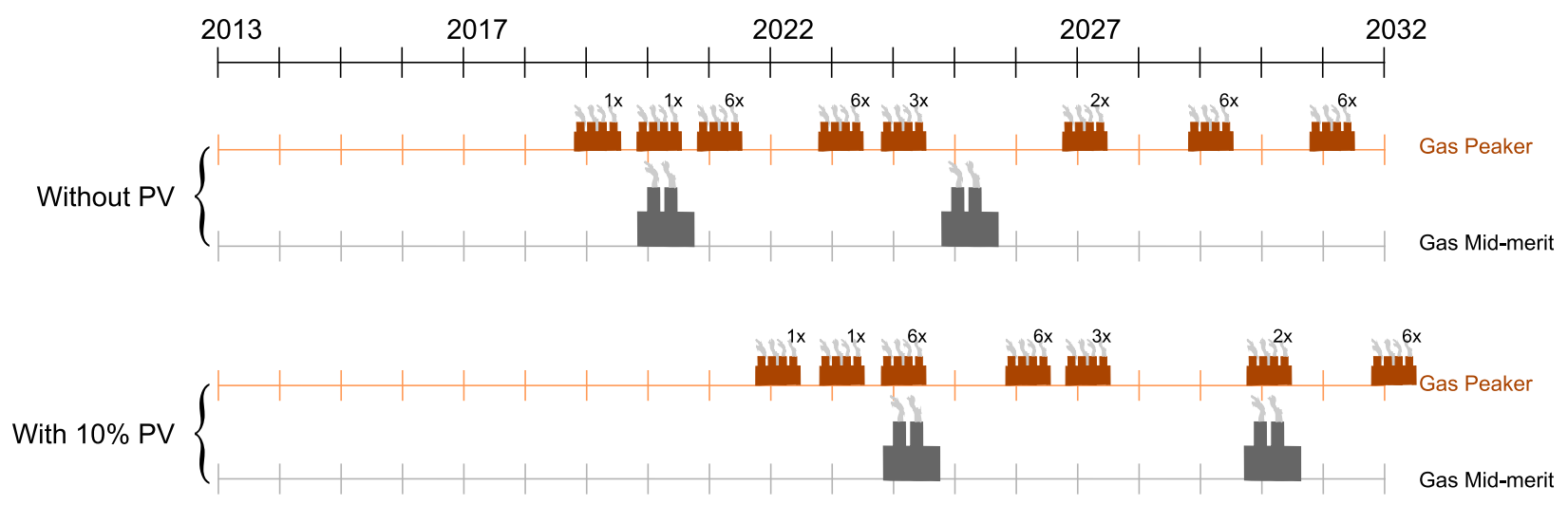

Figure 7. Generation Investment Deferral for the SW Utility with $10 \%$ PV 

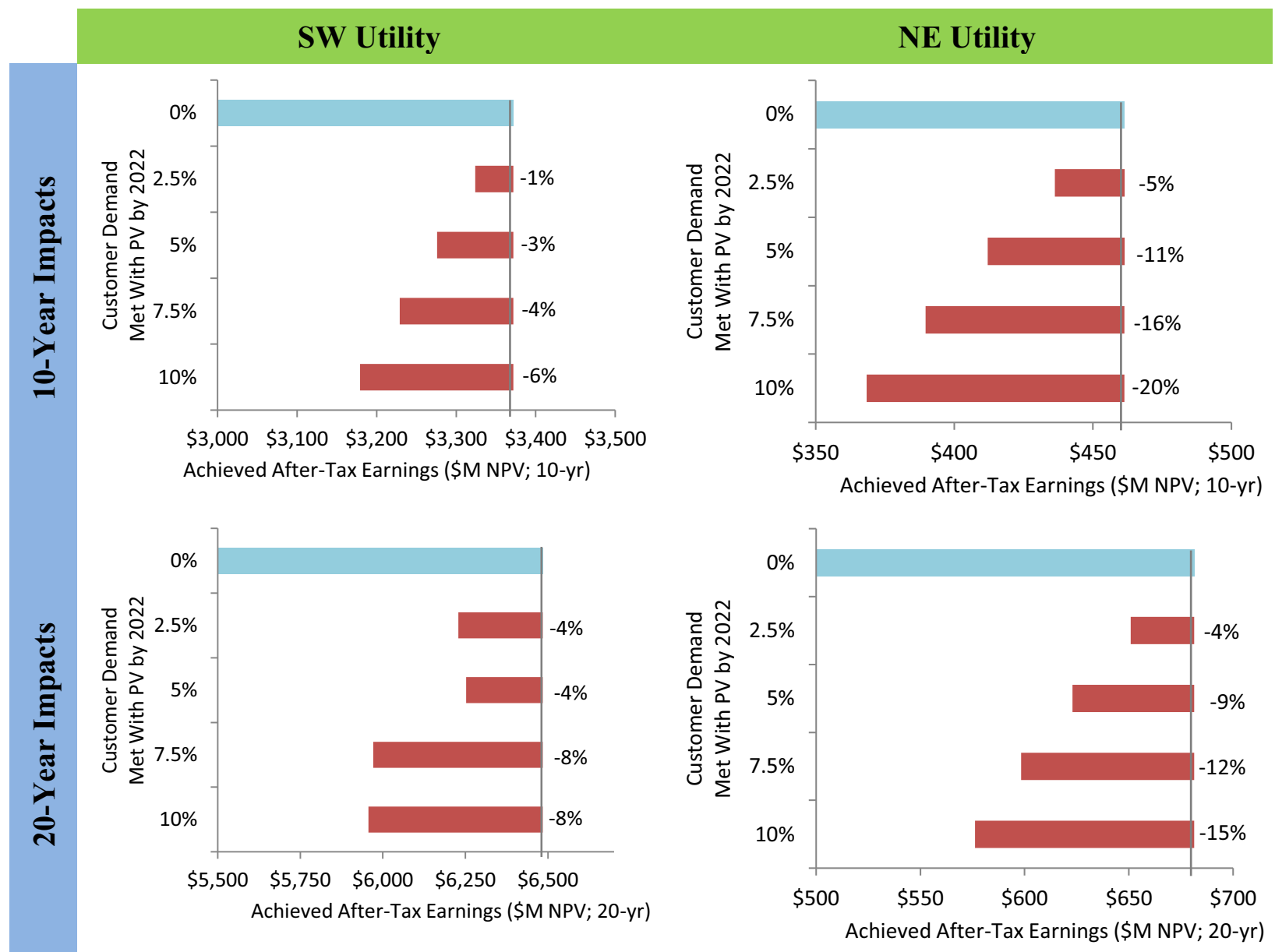

Figure 8. Reduction in Achieved After-Tax Earnings 


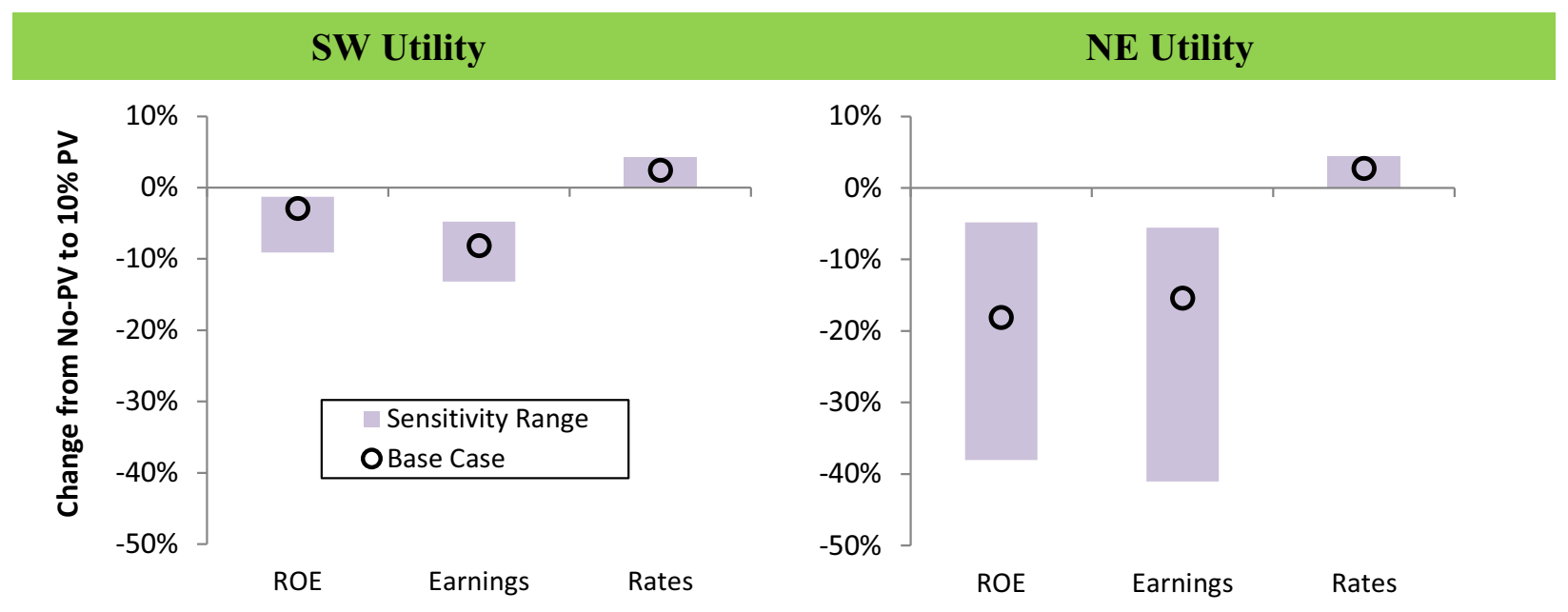

Figure 9. Impacts of Customer-Sited PV across Sensitivity Cases 

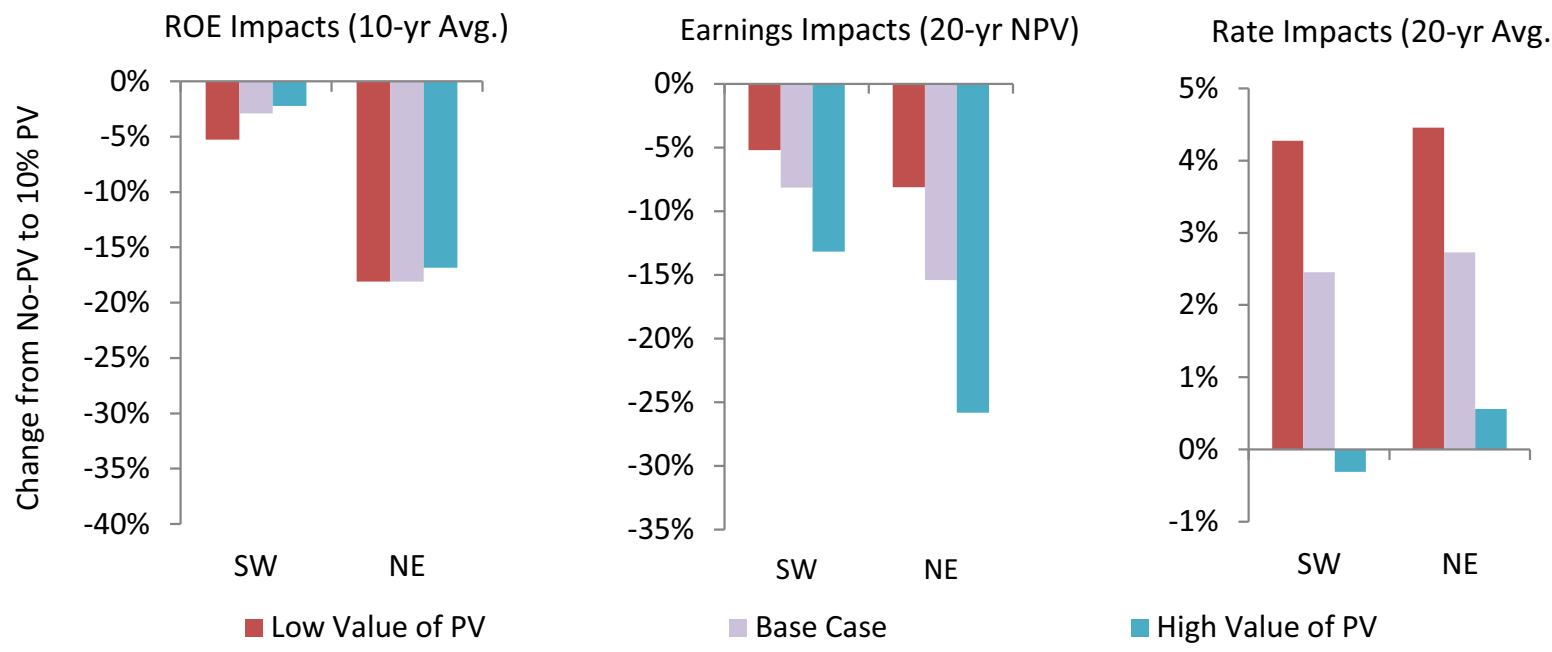

Figure 10. Sensitivity of PV Impacts to Value of Solar 